\title{
Complementary Effects of Crude Ethanol Phytolacca dodecandra (L' Herit) Extracts with House Characteristics on Densities of Indoor Resting Mosquitoes in Western Kenya
}

Yugi Jared Owiti $\square$

School of Science and Technology, University of Kabianga, P. O. Box 20230-20300, Kericho-Kenya

ॠ Corresponding author email: jowiti@kabianga.ac.ke; yugijared@gmail.com

Journal of Mosquito Research, 2020, Vol.10, No.3 doi: 10.5376/jmr.2020.10.0003

Received: 21 Aug., 2020

Accepted: 30 Oct., 2020

Published: 20 Nov., 2020

Copyright $₫ 2020$ Yugi, This is an open access article published under the terms of the Creative Commons Attribution License, which permits unrestricted use, distribution, and reproduction in any medium, provided the original work is properly cited.

Preferred citation for this article:

Yugi J.O., 2020, Complementary effects of crude ethanol Phytolacca dodecandra (L' Herit) extracts with house characteristics on densities of indoor resting mosquitoes in Western Kenya, Journal of Mosquito Research, 10(3): 1-10 (doi: 10.5376/jmr.2020.10.0003)

\begin{abstract}
Intensive use of insecticide treated nets, indoor residual sprays and timely treatment of malaria patients saw reduced malaria parasitaemia from $11 \%$ to $8 \%$ by 2015 . However, the sorry housing characteristics in a number of homesteads in Kenya, threaten this achievement. This study meant to evaluate the complementary effect of crude ethanol Phytolacca dodecandra (Endod) extracts with housing characteristics on density of indoor resting mosquitoes. A completely random block design was used to sample experimental houses and a four by seven factorial design used to sample indoor resting mosquitoes using resting boxes treated with Endod extracts. House characteristics and Endod treatments were taken as independent, mosquitoes as dependent variable and unsprayed (plain) resting boxes as control. Of recovered mosquitoes, Culicines (4.41 \pm 0.03$)$ were more abundant than Anophelines (2.65 \pm 0.04$)$. High [(3.05 \pm $0.14)$, anopheline (5.03 \pm 0.35$)$, culicine] and least [(2.83 \pm 0.14$)$, anopheline (3.48 \pm 0.21$)$, culicine] mosquitoes were found in houses without and with highest number of nets respectively. The numbers however, differed significantly $[(\mathrm{df}=1 ; \mathrm{F}=27.436 ; \mathrm{p}<0.001)$, no net $(\mathrm{df}=1 ; \mathrm{F}=6.669 ; \mathrm{p}<0.012)$, three nets] irrespective of species. Most anophelines $(2.32 \pm 0.09)$ and Culicines (3.73 \pm 0.26$)$ were found in houses with open and closed eaves respectively. It is concluded that effectiveness of crude ethanol Endod extracts on indoor resting mosquitoes is dependent on house characteristics, that crude extracts of Endod repels mosquitoes and that it could be used as an alternative insecticide to reduce the risk and burden of mosquito borne infections.
\end{abstract}

Keywords Phytolacca dodecantra; Anopheline; Culicine; Crude extracts; House characteristics; Resting boxes

\section{Background}

Malaria parasitemia levels were reported to have declined from $11 \%$ in 2010 to $8 \%$ in 2015 (WHO, 2018) probably due to increased use of insecticide treated nets (ITNs), indoor residual spraying (IRS), early diagnosis and prompt treatment (Bhatt et al., 2015). However, malaria transmission has continued to be observed even in areas with high coverage of these interventions (Killeen, 2014). This has been due to among other factors house characteristics. House characteristics in the context of this study is a description of all composite components that include structural design, modification, accessories, activities and residency. These features are important and have been reported to influence mosquito distribution (Mburu et al., 2018; Kaindoa et al., 2018; Jatta et al., 2018; Ngadjeu et al., 2020) in different ways. House characteristics complemented with indoor activities such as cooking, and indoor tethering of livestock provides not only optimal temperature and microclimate (Paaijmans and Thomas, 2011; Afrane et al., 2006) for survival but also gives the mosquito an opportunity to access blood meals.

Increased presence of household openings, such as windows, eaves and occupancy (Ricci, 2012; Roberts and Matthews, 2016; Bannister-Tyrrell et al., 2017; Mugwagwa et al., 2017), have been associated with increased entry (Lwetoijera et al., 2013; Haque et al., 2013) and buildup of indoor resting mosquitoes that have increased parasite prevalence (Konradsen et al., 2003) and malaria burden (Lwetoijera et al., 2013; Bradley et al., 2013). The elephant in the house in most Kenyan household is the challenge in accessing quality housing (Arvantis, 2013; Mbaka, 2013; Ochieng et al., 2017). This exposes most Kenyans to the mercies of indoor resting or visiting mosquitoes and mitigating against this would require managing the numbers by capturing and killing or simply making the house impenetrable. 
Barricading the houses to make it impenetrable to mosquitoes may be a tall order but trapping and killing may be easy to achieve. A number of traps have been designed to this end and used for entomological monitoring (Mburu et al., 2019), retaining (Pombi et al., 2014; Kreppel et al., 2015) and poisoning (Chaiphongpachara et al., 2018) recovered mosquitoes. These traps have not only proven effective in model and efficiency (WHO, 2018) but have also provided surveillance data (Becker et al., 2013), that has helped in the management of mosquito numbers and by extension mosquito-borne diseases (Jöst et al., 2011) and nuisance (Jackson et al., 2012).

Though the traps and improved house quality have done well, synchronous effect of both especially insecticide treated traps has not been evaluated. This study reports on the complementary effect of crude ethanol fruit extracts of Phytolacca dodecandra (hereafter Endod) applied in simple mosquito resting boxes with house characteristics (eave, presences or absence and use of various types of nets for protection, number of individuals sleeping under or without nets and number of persons resident in a house) on densities of indoor resting mosquitoes and by extension their impacts on human health (Osório et al., 2014).

\section{Results}

More Culicine than Anopheline mosquitoes were recovered from the simple resting boxes and though the numbers were small, they were significantly different $(p<0.001)$ regardless of species (Table 1$)$. A higher number of mosquitoes were found in houses without insecticide treated nets. The number however, reduced with increased number of nets and differed significantly $(p<0.02)$ irrespective of mosquito species or net type (Table 2$)$. In all cases regardless of eve, wall type, fumigant (Mortein Doom ${ }^{\circledR}$ ) used or otherwise, the density of captured culicine differed significantly $(p<0.02)$ and exceeded those of Anopheline (Table 3). Interestingly, though the densities of captured mosquitoes reduced with increased number of individuals sleeping under nets, the numbers differed significantly $(p<0.05)$, irrespective of species (Table 4). High densities of mosquitoes were recovered from houses with the highest number of individuals sleeping under no net and though the numbers didn't follow any particular trend they differed significantly $(p<0.02)$, mosquito species not withstanding (Table 5).

Table 1 Mosquito groups sampled by resting boxes. Numbers are represented as means and standard error of means (SEM)]

\begin{tabular}{|c|c|c|c|c|c|c|}
\hline \multirow[t]{2}{*}{ Mosquito type } & \multirow{2}{*}{ Mean \pm SEM } & \multirow[t]{2}{*}{$\mathrm{t}$} & \multirow[t]{2}{*}{ df } & \multirow[t]{2}{*}{$P$} & \multicolumn{2}{|c|}{$95 \%$ Confidence Interval of the Difference } \\
\hline & & & & & Lower & Upper \\
\hline Anopheline & $2.65 \pm 0.04^{\mathrm{a}}$ & 70.051 & 643 & 0.000 & 2.57 & 2.72 \\
\hline Culicine & $4.41 \pm 0.03^{\mathrm{a}}$ & 128.192 & 643 & 0.000 & 4.3421 & 4.4772 \\
\hline
\end{tabular}

Note: df: Degree of freedom; $\mathrm{t}$ : $\mathrm{t}$ statistical factor for student $\mathrm{t}$ test; $P$ : Probability for the level of significance; $P$ was taken as significant at $p<0.05$; Rows having mean percentage mortality superscripted with the same letter "a" indicate significance difference in the densities of mosquito species sampled by the resting boxes

Table 2 Impact of quantity and net type on density of indoor resting mosquitoes; Effects represented as means and standard error of means (SEM)]

\begin{tabular}{|c|c|c|c|c|c|c|}
\hline \multirow[t]{2}{*}{ Parameter } & \multirow[t]{2}{*}{ Status } & \multicolumn{2}{|c|}{ Mosquito Type } & \multirow[t]{2}{*}{ df } & \multirow[t]{2}{*}{$\mathrm{F}$} & \multirow[t]{2}{*}{$P$} \\
\hline & & Anopheline & Culicine & & & \\
\hline \multirow[t]{4}{*}{ Number of mosquito nets within the house } & Zero & $3.05 \pm 0.14^{\mathrm{a}}$ & $5.03 \pm 0.35^{\mathrm{a}}$ & 1 & 27.436 & 0.000 \\
\hline & One & $3.08 \pm 0.15^{\mathrm{a}}$ & $4.74 \pm 0.29^{\mathrm{a}}$ & 1 & 25.554 & 0.000 \\
\hline & Two & $3.01 \pm 0.12^{\mathrm{a}}$ & $4.18 \pm 0.31^{\mathrm{a}}$ & 1 & 12.219 & 0.001 \\
\hline & Three & $2.83 \pm 0.14^{\mathrm{a}}$ & $3.48 \pm 0.21^{\mathrm{a}}$ & 1 & 6.669 & 0.011 \\
\hline \multirow[t]{5}{*}{ Treated insecticide Net (ITN) used } & Plain net & $2.88 \pm 0.14^{\mathrm{a}}$ & $5.14 \pm 0.36^{\mathrm{a}}$ & 1 & 35.438 & 0.000 \\
\hline & Olyset & $2.46 \pm 0.09^{\mathrm{a}}$ & $3.75 \pm 0.35^{\mathrm{a}}$ & 1 & 13.600 & 0.000 \\
\hline & Permanet & $3.38 \pm 0.16^{\mathbf{a}}$ & $4.50 \pm 0.35^{\mathrm{a}}$ & 1 & 6.247 & 0.014 \\
\hline & Olyset+Parmanet & $3.01 \pm 0.12^{\mathrm{a}}$ & $3.69 \pm 0.20^{\mathrm{a}}$ & 1 & 8.327 & 0.005 \\
\hline & Other ITN & $2.32 \pm 0.09^{\mathrm{a}}$ & $3.08 \pm 0.26^{\mathrm{a}}$ & 1 & 7.563 & 0.007 \\
\hline
\end{tabular}

Note: df: Degree of freedom; F: F statistical factor ANOVA test; $P$ : Probability for the level of significance; $\mathrm{P}$ was taken as significant at $p<0.05$; Rows having mean and standard error of mean (SEM) superscripted with the same letter " $\mathrm{a}$ " indicate significance difference in the influence of the status of parameters on the densities of mosquito species sampled 
Journal of Mosquito Research 2020, Vol.10, No.3, 1-10

http://emtoscipublisher.com/index.php/jmr

Table 3 Impact of house characteristics on the densities of indoor resting mosquitoes. Impact represented as means and standard error of means (SEM)]

\begin{tabular}{|c|c|c|c|c|c|c|}
\hline \multirow[t]{2}{*}{ Parameter } & \multirow[t]{2}{*}{ Status } & \multicolumn{2}{|c|}{ Mosquito Type } & \multirow[t]{2}{*}{$\mathrm{df}$} & \multirow[t]{2}{*}{$\mathrm{F}$} & \multirow[t]{2}{*}{$\mathrm{P}$} \\
\hline & & Anopheline & Culicine & & & \\
\hline \multirow[t]{2}{*}{ Eave type } & Closed & $2.32 \pm 0.09^{\mathrm{a}}$ & $3.08 \pm 0.26^{\mathrm{a}}$ & 1 & 7.563 & 0.007 \\
\hline & Open & $2.15 \pm 0.05^{\mathrm{a}}$ & $3.73 \pm 0.26^{\mathrm{a}}$ & 1 & 34.947 & 0.000 \\
\hline \multirow[t]{2}{*}{ Wall type } & Mud & $2.16 \pm 0.05^{\mathrm{a}}$ & $3.41 \pm 0.23^{\mathrm{a}}$ & 1 & 28.099 & 0.000 \\
\hline & Plastered & $2.73 \pm 0.17^{\mathrm{a}}$ & $4.47 \pm 0.24^{\mathrm{a}}$ & 1 & 35.983 & 0.000 \\
\hline \multirow[t]{2}{*}{ Fumigant used } & None & $3.50 \pm 0.17^{\mathrm{a}}$ & $4.28 \pm 0.26^{\mathrm{a}}$ & 1 & 6.504 & 0.012 \\
\hline & Doom & $2.51 \pm 0.10^{\mathrm{a}}$ & $4.02 \pm 0.40^{\mathrm{a}}$ & 1 & 13.657 & 0.000 \\
\hline
\end{tabular}

Note: df: Degree of freedom; F: F statistical factor ANOVA test; $P$ : Probability for the level of significance; P was taken as significant at $p<0.05$; Rows having mean percentage mortality superscripted with the same letter "a" indicate significance difference in the influence of the status of parameters on the densities of mosquito species sampled

Table 4 Impact of people sleeping under nets on densities of indoor resting mosquitoes. Effects represented as means and standard error of means (SEM)]

\begin{tabular}{llllll}
\hline Number of individuals sleeping under nets & \multicolumn{2}{l}{ Mosquito species } & df & F & \multirow{2}{*}{ P } \\
\cline { 2 - 5 } & Anopheline & Culicine & & \\
\hline Two & $2.94 \pm 0.10^{\mathbf{a}}$ & $4.43 \pm 0.26^{\mathbf{a}}$ & 1 & 37.236 & 0.000 \\
Three & $2.80 \pm 0.13^{\mathrm{a}}$ & $4.37 \pm 0.21^{\mathrm{a}}$ & 1 & 32.222 & 0.000 \\
Four & $2.67 \pm 0.09^{\mathrm{a}}$ & $3.68 \pm 0.16^{\mathrm{a}}$ & 1 & 31.173 & 0.000 \\
Five & $2.64 \pm 0.09^{\mathrm{a}}$ & $3.63 \pm 0.19^{\mathrm{a}}$ & 1 & 22.211 & 0.000 \\
Six & $2.46 \pm 0.09^{\mathrm{a}}$ & $2.97 \pm 0.16^{\mathrm{a}}$ & 1 & 7.844 & 0.006 \\
\hline
\end{tabular}

Note: df: Degree of freedom; F: F statistical factor ANOVA test; $P$ : Probability for the level of significance; P was taken as significant at $p<0.05$; Rows having mean percentage mortality superscripted with the same letter "a" indicate significance difference in the influence of the status of parameters on the densities of mosquito species sampled

Table 5 Impact of number of residencies on densities of indoor resting mosquitoes; Effects represented as means and standard error of means (SEM)]

\begin{tabular}{llllll}
\hline Number of residents per experimental house & \multicolumn{2}{l}{ Mosquito type } & df & F & P \\
\cline { 2 - 5 } & Anopheline & Culicine & & & \\
\hline One & $2.88 \pm 0.12^{\mathrm{a}}$ & $4.17 \pm 0.27^{\mathrm{a}}$ & 1 & 26.928 & 0.000 \\
Two & $2.82 \pm 0.14^{\mathrm{a}}$ & $4.16 \pm 0.29^{\mathrm{a}}$ & 1 & 17.188 & 0.000 \\
Three & $2.81 \pm 0.10^{\mathrm{a}}$ & $4.09 \pm 0.32^{\mathrm{a}}$ & 1 & 12.711 & 0.000 \\
Four & $2.68 \pm 0.11^{\mathrm{a}}$ & $3.89 \pm 0.22^{\mathrm{a}}$ & 1 & 19.179 & 0.000 \\
Five & $2.66 \pm 0.11^{\mathrm{a}}$ & $3.88 \pm 0.23^{\mathrm{a}}$ & 1 & 23.220 & 0.000 \\
Six & $2.55 \pm 0.11^{\mathrm{a}}$ & $3.28 \pm 0.20^{\mathrm{a}}$ & 1 & 10.264 & 0.002 \\
\hline
\end{tabular}

Notes: df: Degree of freedom; F: F statistical factor ANOVA test; $P$ : Probability for the level of significance; P was taken as significant at $p<0.05$; Rows having mean percentage mortality superscripted with the same letter "a" indicate significance difference in the influence of the status of parameters on the densities of mosquito species sampled

\section{Discussion}

In this study, complementary effect of crude ethanol extracts of Endod applied in simple mosquito resting boxes and four major aspects of house characteristics on density of indoor resting mosquitoes were examined: Structure of house wall, presence and use of ITNs, number of individuals sleeping under and without ITNs and number of occupants per house. The results were a recovery of two important species of mosquitoes (Anopheline and Culicine) involved in the transmission of mosquito borne diseases such as malaria (Ndenga et al., 2006; Tchouassi et al., 2012; Dia et al., 2013) and viruses (Ochieng et al., 2013) in Western Kenya (Karungu et al., 2019).

In this study, a high number of culicine compared to Anopheline mosquitoes were found resting indoors. This being a natural setting inhabited by both wild, domesticated as well as human beings, it was natural for the numbers of 
culicines to surpass anophelines as culicines are not only found in all zoogeographical areas (Bhattacharya et al., 2016) but are also dominant in human settlements (Ciota and Kramer, 2013).

By default, closed eaves should result in fewer indoor resting mosquitoes and if the mosquitoes are to gain entry, then the number will depend on the degree of eave closure. This however, is only true for Anopheles and not culicine (Mburu et al., 2018). In the current study closed eaves were more restrictive to Culicine than Anopheline mosquitoes though the difference was not significant. This was contrary to an observation of houses with fully closed eaves that were observed to have reduced rates of house entry by anopheline mosquitoes compared to houses with fully open eaves (Kirby et al., 2009; Ogoma et al., 2009 Menger et al., 2016; Mburu et al., 2018).

A relatively higher density of indoor resting mosquitoes was found resting in cement plastered walls regardless of species, an observation that was consistent with that made earlier on the influence of house characteristics on mosquito distribution (Mburu et al., 2018; Kaindoa et al., 2018; Lwetoijera et al., 2013). The findings herein, however, was contrary to Ngadjeu et al. (2020) observation that noted that houses constructed with cement walls or walls with mixed materials demonstrated a lower density of mosquitoes than houses with mud or plank (Ngadjeu et al., 2020) walls. Plastered walls as per the observation made here was more attractive to mosquitoes and therefore would be less protective against mosquito bite and mosquito borne diseases contrary to an observation by Tusting et al. (2015) that envisioned increased protection with house improvement.

A high number of Anopheline and Culicine mosquitoes were observed resting indoors despite availability and use of ITNs. This observation was similar to that made by Machani et al. (2020) for An. gambiae and An. funestus in the presence of long lasting insecticidal nets (LLINs) but contrary to the expectation of Mathenge et al. (2001) and Malima et al. (2008) who believed that using ITNs in houses would have led to reduced rate of entry or increased exit of adult mosquitoes respectively. The logical explanation of this phenomenon would probably be due to the unpredictable use of ITNs by different individuals within households that would result in some people being unprotected (Korenromp et al., 2003; Eisele et al., 2009; Macintyre et al., 2012). These people would not only be fair targets but would enhance the attractiveness of the houses leading to high numbers of visiting mosquitoes despite substantial increase in the number of households owning ITNs (WHO, 2012). This is consistent with an earlier observation that houses in which only some residents used LLINs the previous night had more An. arabiensis and An. gambiae s.s. than houses in which all residents used LLINs the previous night (Gimnig et al., 2003). This is suggestive that people not sleeping under LLINs, even in houses with LLINs served as baits for the blood seeking mosquitoes. Another explanation is that either the strain of mosquitoes that dared entre house with such lethal provisions were from a breed resistant to pyrethroid insecticide as earlier observed in western Kenya (Ochomo et al., 2014; Wanjala et al., 2015), or their survival of onslaught or repellence was due to mounted behavioural (Siegert et al., 2009) and or physiological (Ranson and Lissenden, 2016) defenses.

In the current study a higher number of mosquitoes were captured in houses with least occupants and where the least number of inhabitants slept under nets. This was contrary to popular observation that as the numbers of individuals increased in a house so did hosts' properties such as odorants, body heat and body mass that would naturally make the houses attractive to the mosquitoes (Lyimo and Ferguson, 2009; Takken and Verhulst, 2013). Naturally mosquitoes are lured into human habitats by odorants such as $\mathrm{CO}_{2}$ and exuded heat pinpoint the exact position of the individual. It was therefore expected that the presence of increased residents would equal high numbers of mosquitoes in the residential houses (Lwetoijera et al., 2013; Kaindoa et al., 2016). This is because when numbers of residents increase so is the source of blood meal. However, for some reason it's either that the mosquitoes did not find the houses attractive and if they entered, they must have hurriedly exited leaving very few of them behind. If this was the case, then this is beneficial as it meant that Endod plant extracts applied in the boxes did repulse or repel the mosquitoes and made them exit the buildings. This would imply that the otherwise increased risk that would have been enhanced by increased densities of mosquitoes (Harbison et al., 2006; Odiere et al., 2007) would be reverted. In the event that all the factors are actualize and optimally operationalized then it is expected 
that fewer mosquitoes will be entering (Kirby et al., 2009;Atieliet al., 2009; Kampango et al., 2013) and roaming within the homes resulting in reduce mosquito bites (Atieliet al., 2009; Ogoma et al., 2009; Kirby et al., 2010; von Seidlein et al., 2017) and reduced anaemia among the inhabitants (Kirby et al., 2009).

\section{Materials and Methods}

\subsection{Study site}

The current study was conducted in Korando "B" Sub-location in Western Kenya. The site is about $11.4 \mathrm{~km}$ from the City of Kisumu along Kisumu-Busia/Mumias road. Populace here are mainly Luo ethnic community who engage in a myriad of economic activities to eke a living.

\subsection{Mosquito Resting boxes}

Simple resting boxes for the capture and sampling mosquitoes were made using galvanized wire frame measuring $30 \mathrm{~cm} \times 30 \mathrm{~cm} \times 30 \mathrm{~cm}$ and designed in a similar way as one described by Crans (1989). Bright blue and black pieces of cloth were sewn out and inside respectively and square pieces of cartons placed between them for reinforcement (Figure 1).

\subsection{Endod plant materials acquisition, extraction and preparation}

Mature green fruits of Endod plant were sourced, identified and voucher specimen deposited as earlier described (Yugi et al., 2015). The plant parts were shade dried at room temperature, grounded and extracted using ethanol following Das et al. (2010) procedure. Preparation of $80 \mathrm{mg}$ stokes crude ethanol Endod extract was made by dissolving the same in $100 \mathrm{ml}$ of rain water and the resulting solution used to spray the inner fibric of test resting boxes.

\subsection{Selection of houses for experimentation}

A completely randomized block design (Kothari, 2004) was used to select houses for study. Four blocks of a $\mathrm{km}^{2}$ apart were identified and homesteads within sampled randomly. Seven houses per block were purposively selected in view of characteristics such as wall, eve and insecticide treated net and fumigant type used within.

\subsection{Sampling Indoor resting mosquitoes}

A four by seven $(4 \times 7)$ factorial research design (Kothari, 2004) was used to shuffle resting boxes used in trapping and sampling of indoor resting mosquitoes from experimental houses. To each experimental house, a simple resting box baited with a dirty sock with strong human foot scent was placed. The trap was placed on the floor at a corner in no particular fashion (Mboera, 2005). The boxes were left to stay in the houses undisturbed for two days before shuffling. Shuffling was done in four phases. In phase one, boxes from one block was shuffled with those of the other block and in phase two, boxes were shuffled between rooms within the same block. The shuffling was continued until a box had a chance to be in every block and house in the set up respectively.

Trapped mosquitoes were aspirated from the boxes every morning by 6.30 hours. This was done using a battery powered aspirator (procopak) with the aid of torch light for illumination. The recovered mosquitoes were put in plastic mosquito holding cups (Figure 2) and transported to the laboratory for processing. Gillies and Coetzee (1987), identification key was used to identify the mosquitoes to species level.

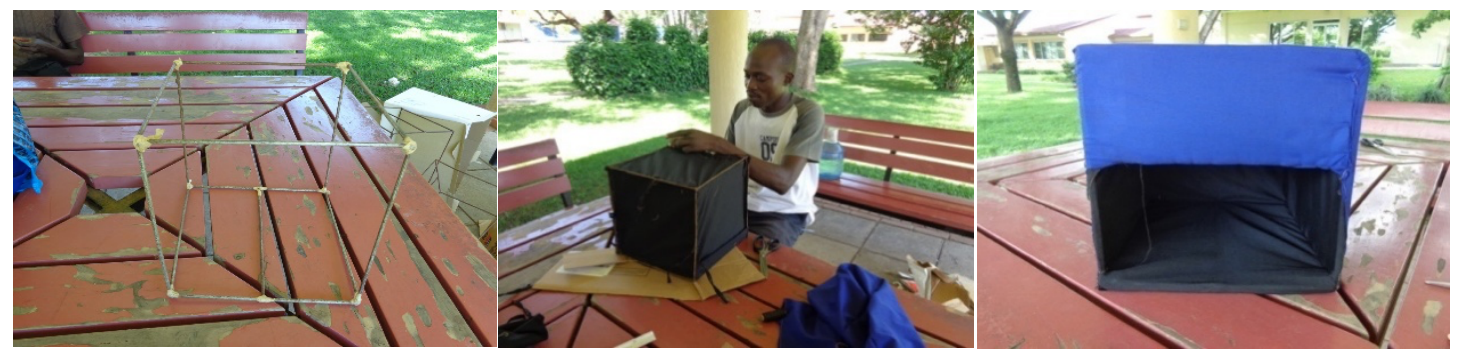

Figure 1 Assembling a simple mosquito resting boxes (modified after Harbison et al., 2006) for indoor resting mosquito sampling 


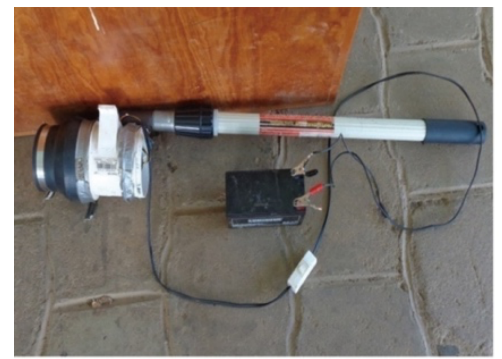

Bilge blower 4" inline model 240

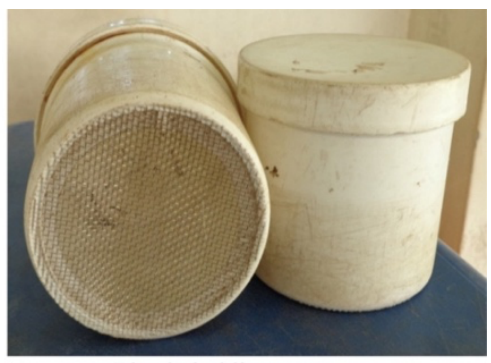

Plastic holding cups

Figure 2 Aspiration equipment for collecting mosquitoes from resting boxes

\subsection{Data analysis}

Data was organized in excel and tested for conformation to the assumptions of normality. Descriptive statistics was used to report on the densities of captured mosquitoes. Student $T$ test was used to assess the level of comparative attractiveness of the experimental houses to the indoor resting mosquitoes. One-way analysis of variance (ANOVA) was used to analyze and report on the effects of house characteristics on densities of captured mosquitoes. All statistical analysis was performed using Statistical Package for Social Scientists (SPSS) version 22.

\section{Conclusion}

In the foregoing discussion, its apparent that house characteristics influence resident mosquito density and by extension burden of mosquito borne infections. It is also apparent that the use of Endod extracts in the treatment of resting boxes impacted densities of indoor residual mosquitoes. A combination of Endod in resting boxes together with improved house characteristics can be used as an alternative tool against mosquito borne diseases.

\section{Acknowledgements}

The author thanks Harnnel Owiti and Richard Amito, for culturing all mosquitoes used in this study, Centre for Global Health Research/Kenya Medical Research Institute (CGHR/KEMRI) for mosquitoes, laboratory space and equipment. National Commission for Science, Technology and Innovation (NACOSTI), Kenya is also thanked for funding the project.

\section{References}

Afrane Y.A., Zhou G., Lawson B.W., Githeko A.K., and Yan G., 2006, Effects of microclimatic changes caused by deforestation on the survivorship and reproductive fitness of Anopheles gambiae in western Kenya highlands, American Journal of Tropical Medicine and Hygiene, 74(5):772-778

https://doi.org/10.4269/ajtmh.2006.74.772

PMid: 16687679

Arvantis Y., 2013, African Housing Dynamics: Lessons from the Kenyan Market, Chief Economist Complex/AEB, 4(3): 1-12

Atieli H., Menya D., Githeko A., and Scott T., 2009, House design modifications reduce indoor resting malaria vector densities in rice irrigation scheme area in western Kenya, Malaria Journal, 8(1): 1-9

https://doi.org/10.1186/1475-2875-8-108

PMid:19454025 PMCid:PMC2688520

Bannister-Tyrrell M., Verdonck K., Hausmann-Muela S., Gryseels C., Muela R.J., and Peeters G.K., 2017, Defning micro-epidemiology for malaria elimination: systematic review and meta-analysis, Malaria Journal, 16(1):164

https://doi.org/10.1186/s12936-017-1792-1

PMid:28427389 PMCid:PMC5399382

Becker N., Geier M., Balczun C., Bradersen U., Huber K., Kiel E., Krüger A., Lühken R., Orendt C., Plenge-Bönig A., Rose A., Schaub G.A., and Tannich E., 2013, Repeated introduction of Aedes albopictus into Germany, July to October 2012, Parasitology Research, 112(4): 1787-1790 https://doi.org/10.1007/s00436-012-3230-1

PMid:23242268

Bhatt S., Weiss D.J., Cameron E., Bisanzio D., Mappin B., Dalrymple U., Battle K., Moyes C.L., Henry A., Eckhoff P.A., Wenger E.A., Briët O., Penny M.A., Smith T.A., Bennett A., Yukich J., Eisele T.P., Griffin J.T., Fergus C.A., Lynch M., Lindgren F., Cohen J.M., Murray C.L.J., Smith D.L., Hay S.I., Cibulskis R.E., and Gething P.W., 2015, The effect of malaria control on Plasmodium falciparum in Africa between 2000 and 2015, Nature, 526(7572): 207-211 https://doi.org/10.1038/nature15535

Bhattacharya S., and Basu, P., 2016, The southern house mosquito, Culexquinquefasciatus: profile of a smart vector, Journal of Entomology and Zoological Studies, 4(2): 73-81 
Bradley J., Rehman A.M., Schwabe C., Vargas D., Monti F., Ela C., Riloha M., and Kleinschmidt I., 2013, Reduced prevalence of malaria infection in children living in houses with window screening or closed eaves on Bioko Island, Equatorial Guinea,PLoS ONE 8: e80626 https://doi.org/10.1371/journal.pone.0080626 PMid:24236191 PMCid:PMC3827414

Chaiphongpachara T., Padidpoo O., Chansukh K.K., and Sumruayphol S., 2018, Efficacies of five edible mushroom extracts as odor baits for resting boxes to attract mosquito vectors: A field study in Samut Songkhram Province, Thailand. Tropical Biomedicine, 35(3): 653-663

Ciota A.T., and Kramer, L.D., 2013, Vector-virus interactions and transmission dynamics of West Nile virus, Viruses, 5(12): 3021-3047

https://doi.org/10.3390/v5123021 PMid:24351794 PMCid:PMC3967159

Crans W.J., 1989, Resting boxes as mosquito surveillance tools, In Proceedings of the 82nd Annual Meeting of the New Jersey Mosquito Control Association, Inc., pp. 53-57

Das K., Tiwari R.K.S., and Shrivastava D.K., 2010, Techniques for evaluation of medicinal plant products as antimicrobial agent: Current methods and future trends, Journal of Medical and Plant Research, 4(2): 104-111

Dia I, Guelbeogo M.W., and Ayala D., 2013, Advances and perspectives in the study of the malaria mosquito Anopheles funestus, In: Manguin S, editor. Anopheles Mosquitoes, New Insights into Malaria Vectors, London: Intech. pp. 828 https://doi.org/10.5772/55389

Eisele T.P., Keating J., Littrell M., Larsen D., and Macintyre K., 2009, Assessment of insecticide-treated bednet use among children and pregnant women across 15 countries using standardized national surveys, American Journal of Tropical Medicine and Hygiene, 80(2):209-214

https://doi.org/10.4269/ajtmh.2009.80.209 PMid:19190215

Gillies T.M., and Coetzee M., 1987, Supplement of the Anopheles of Africa South of Sahara (Afrotropical Region), Johannesburg, Republic of South Africa, Pub South African Institute of MedicalReseach, 143

Gimnig J.E., Vulule J.M., Lo T.Q., Kamau L., Kolczak M.S., Phillips-Howard P.A., MathengeE.M., KuileF.O., NahlenB.L., HightowerA.W., and Hawley W.A., 2003,Impact of permethrin-treated bed nets on entomologic indices in an area of intense year-round malaria transmission,American Journal of Tropical Medicine and Hygiene, 68:16-22

https://doi.org/10.4269/ajtmh.2003.68.16

PMid:12749481

Haque U., Glass G.E., Bomblies A., Hashizume M., Mitra D., Noman N., Haque W., Kabir M.M., Yamamoto T., and Overgaard H.J., 2013, Risk factors associated with clinical malaria episodes in Bangladesh: a longitudinal study,American Journal of Tropical Medicine and Hygiene,88(4): 727-732

https://doi.org/10.4269/ajtmh.12-0456

PMid:23419363 PMCid:PMC3617860

Harbison J.E., Mathenge E.M., Misiani G.O., Mukabana W.R., and Day J.F., 2006,A simple method for sampling indoor-resting malaria mosquitoes Anopheles gambiae and Anopheles funestus (Diptera: Culicidae) in Africa, Journal of Medical Entomology, 43(3): 473-479 https://doi.org/10.1603/0022-2585(2006)43[473:ASMFSI]2.0.CO;2

Jackson M.J., Gow J.L., Evelyn M.J., McMahon T.J.S., Howay T.J., Campbell H., Blancard J., and Thielman A., 2012, An evaluation of the effectiveness of a commercial mechanical trap to reduce abundance of adult nuisance mosquito populations, Journal of American Mosquito Control Association, 28(4): 292300

https://doi.org/10.2987/12-6241R.1

PMid:23393751

Jatta E., Jawara M., Bradley J., Jeffries D., Kandeh B., KnudsenJ.B., Wilson A.L., Pinder M., D'Alessandro U., and Lindsay, S.W., 2018, How house design affects malaria mosquito density, temperature, and relative humidity: an experimental study in rural Gambia, Lancet Planet Health 2: e498-508 https://doi.org/10.1016/S2542-5196(18)30234-1

Jöst H., Bialonski A., Maus D., Sambri V., Eiden M., Groschup M.H., Gunther S., Becker N., and Schmidt-Chanasit J., 2011, Isolation of Usutu virus in Germany. American Journal of Tropical Medicine and Hygiene, 85(3): 551-553

https://doi.org/10.4269/ajtmh.2011.11-0248

PMid:21896821 PMCid:PMC3163883

Kaindoa E.W., Finda M., Kiplagat J., Mkandawile G., Nyoni A., Coetzee M.,and Okumu F.O., 2018, Housing gaps, mosquitoes and public viewpoints: a mixed methods assessment of relationships between house characteristics, malaria vector biting risk and community perspectives in rural Tanzania, Malaria Journal, 17(1): 298

https://doi.org/10.1186/s12936-018-2473-4

PMid:30200974 PMCid:PMC6131942

Kaindoa E.W., Mkandawile G., Ligamba G., Kelly-Hope L.A., and Okumu F.O., 2016, Correlations between household occupancy and malaria vector biting risk in rural Tanzanian villages: implications for high-resolution spatial targeting of control interventions, Malaria Journal, $15(1): 199$ https://doi.org/10.1186/s12936-016-1268-8

PMid:27067147 PMCid:PMC4828883 
Kampango A., Bragança M., de Sousa B., and Charlwood J.D., 2013, Netting barriers to prevent mosquito entry into houses in southern Mozambique: a pilot study, Malaria Journal, 12(1):1-7

https://doi.org/10.1186/1475-2875-12-99

PMid:23497325 PMCid:PMC3602670

Karungu S., Atoni E., Ogalo J., Mwaliko C., Agwanda B., Yuan Z., and Hu X., 2019, Mosquitoes of etiological concern in Kenya and possible control strategies, Insects, 10(173): 1-23

https://doi.org/10.3390/insects10060173

PMid:31208124 PMCid:PMC6627689

Killeen G., 2014, Characterizing, controlling and eliminating residual malaria transmission, Malaria Journal, 13(1): 330 https://doi.org/10.1186/1475-2875-13-S1-P53

PMCid:PMC4179398

Kirby M.J., Ameh D., Bottomley C., Green C., Jawara M., Milligan P.J., Snell P.C., Conway D.J., and Lindsay S.W., 2009, Effect of two different house screening interventions on exposure to malaria vectors and on anaemia in children in The Gambia: a randomized controlled trial, Lancet,374(9694): 998-1009 https://doi.org/10.1016/S0140-6736(09)60871-0

Kirby M.J., Bah P., Jones C.O.H., Kelly, A.H., Jasseh M., and Lindsay S.W., 2010, Social acceptability and durability of two different house screening interventions against exposure to malaria vectors, Plasmodium falciparum infection, and anemia in children in The Gambia, West Africa, American Journal Tropical Medicine and Hygiene, 83(5): 965-72

https://doi.org/10.4269/ajtmh.2010.10-0311

PMid:21036822 PMCid:PMC2963954

Konradsen F., Amerasinghe P., Hoek W.V.D., Amerasinghe F., Perera D.,and Piyaratne M., 2003, Strong association between house characteristics and malaria vectors in Sri Lanka, American Journal Tropical Medicine and Hygiene, 68(2): 177-181

https://doi.org/10.4269/ajtmh.2003.68.177

PMid:12641408

Korenromp E.L., Miller J., Cibulskis R.E., Cham M.K., Alnwick D., and Dye C., 2003, Monitoring mosquito net coverage for malaria control in Africa: possession vs. use by children under 5 years, Tropical Medicine and International Health, 8(8): 693-703

https://doi.org/10.1046/j.1365-3156.2003.01084.x

PMid: 12869090

Kothari C.R., 2004, Research design: research methodology, methods and techniques, 2nd edition, New Age International Publishers, New Delhi, India, 47-50

Kreppel K.S., Johnson P.C.D., Govella N.J., Pombi M., Maliti D., and Ferguson H.M., 2015, Comparative evaluation of the Sticky-RestingBox-Trap, the standardised resting-bucket-trap and indoor aspiration for sampling malaria vectors, Parasites \& Vectors, 8(1): 462

https://doi.org/10.1186/s13071-015-1066-0

PMid:26383620 PMCid:PMC4573490

Lwetoijera D.W., Kiware S.S., Mageni Z.D., Dongus S., Harris C., Devine GJ, andMajambere S, 2013, A need for better housing to further reduce indoor malaria transmission in areas with high bed net coverage, Parasite \& Vectors, 6(1): 57-63

https://doi.org/10.1186/1756-3305-6-57

PMid:23497471 PMCid:PMC3599311

Lyimo I.N., and Ferguson H.M., 2009, Ecological and evolutionary determinants of host species choice in mosquito vectors, Trends in Parasitolology, 25(4):189196

https://doi.org/10.1016/j.pt.2009.01.005

PMid:19269900

Machani M.G., Ochomo E., Amimo F., Kosgei J., Munga S., Zhou G., Githeko A.K., Yan G., and Afrane Y.A., 2020, Resting behaviour of malaria vectors in highland and lowland sites of western Kenya: Implication on malaria vector control measures, PLoS ONE, 15(2): e0224718 https://doi.org/10.1371/journal.pone.0224718

PMid:32097407 PMCid:PMC7041793

Macintyre K., Littrell M., Hamainza B., Miller J., Eisele T.P., and Keating J., 2012, Determinants of hanging and use of ITNs in the context of near universal coverage in Zambia, Health Policy Plan, 27(4): 316-325

https://doi.org/10.1093/heapol/czr042 PMid:21652576

Malima R.C., Magesa S.M., Tungu P.K., Mwingira V., Magogo F.S., Sudi W., Mosha F.W., Curtis C.F., Maxwell C., and Rowland M., 2008, An experimental hut evaluation of Olyset ${ }^{\circledR}$ nets against anopheline mosquitoes after seven years use in Tanzanian villages., Malaria Journal, $7(1)$ : 38 https://doi.org/10.1186/1475-2875-7-38

PMid:18307802 PMCid:PMC2267806

Mathenge E.M., Gimnig J.E., Kolczak M., Ombok M., Irungu L.W., and Hawley W.A., 2001, Effect of permethrin-impregnated nets on exiting behavior, blood feeding success, and time of feeding of malaria mosquitoes (Diptera: Culicidae) in western Kenya. Journal of Medical Entomology, 38 : 531-536 $\underline{\text { https://doi.org/10.1603/0022-2585-38.4.531 }}$ 
Mbaka S., 2013, How Affordable is Affordable Housing? Muungano Support Trust, Nairobi, Kenya

Mboera L.E.G., 2005, Sampling techniques for adult Afrotropical malaria vectors and their reliability in the estimation of entomological inoculation rate. Tanzania Health Resource Bulletin, 7: 117-124

https://doi.org/10.4314/thrb.v7i3.14248

PMid:16941936

Mburu M.M., Juurlink M., Spitzen J., Moraga P., Hiscox A., Mzilahowa T., Takken W., and McCann R.S., 2018, Impact of partially and fully closed eaves on house entry rates by mosquitoes, Parasite\& Vectors, 11: 383

https://doi.org/10.1186/s13071-018-2977-3

PMid:29970153 PMCid:PMC6029021

Mburu M.M., Zembere K., Hiscox A., Banda J., Phiri K.S., Berg H.V., Mzilahowa T., Takken W., and McCann, R.S., 2019, Assessment oftheSuna trap forsampling mosquitoes indoors andoutdoors, Malaria Journal, 18:51

https://doi.org/10.1186/s12936-019-2680-7

PMid:30795766 PMCid:PMC6387520

Menger D.J., Omusula P., Wouters K., Oketch C., Carreira A.S., Durka M., Derycke J.L., Loy D.E., Hahn B.H., Mukabana W.R., Mweresa C.K., van Loon J.J.A., Takken W., and Hiscox A., 2016, Eave Screening and Push-Pull Tactics to Reduce House Entry by Vectors of Malaria. American Journal of Tropical Medicine and Hygiene, 94(4): 868-878 https://doi.org/10.4269/ajtmh.15-0632 PMid:26834195 PMCid:PMC4824231

Mugwagwa N., Mberikunashe J., Gombe N.T., Tshimanga M., Bangure D., Mungati M., 2017, Erratum to: Factors associated withmalaria infection inHonde valley, Mutasa district, Zimbabwe, 2014: a case control study, BMC Research Notes, 8:829 https://doi.org/10.1186/s13104-017-2745-Z

PMid:28838322 PMCid:PMC5571631

Ndenga B., Githeko A., Omukunda E., Munyekenye G., Atieli H., Wamai P., Mbogo C., Minakawa N., Zhou G., and Yan G., 2006, Population dynamics of malaria vectors in western Kenya highlands, Journal of Medicine Entomology, 43: 200-206

https://doi.org/10.1093/jmedent/43.2.200

PMid:16619599

Ngadjeu C.S., Doumbe Belisse P., Talipouo A., Djamouko Djonkam L., Awono Ambene P., Kekeunou S., Toussile W., Wondji C.S., and Antonio Nkondjio C., 2020, Infuence of house characteristics on mosquito distribution and malaria transmission in the city of Yaoundé, Cameroon, MalariaJournal, 19: 53 https://doi.org/10.1186/s12936-020-3133-Z PMid:32000786 PMCid:PMC6993434

Ochieng C., Lutomiah J., Makio A., Koka H., Chepkorir E., Yalwala S., Mutisya J., Musila L., Khamadi S., Richardson J., Bast J., Schnabel D., Wurapa E., and Sang R., 2013, Mosquito-borne arbovirus surveillance at selected sites in diverse ecological zones of Kenya; 2007-2012, Virology Journal, 10: 140 https://doi.org/10.1186/1743-422X-10-140

PMid:23663381 PMCid:PMC3669043

Ochieng R.R.O., Mbatha C.M., and Syagga P.M., 2017, Determinants of Accessibility to Quality Housing by the Low / Middle Income Earners in Kenya, International Journal of Innovative Research and Knowledge, 2(5): 102-115

Ochomo E., Bayoh N.M., Kamau L., Atieli F., Vulule J., Ouma C., Ombok M., Njagi K., Soti D., Mathenge E., Muthami L., Kinyari T., Subramaniam K., Kleinschmidt I., Donnelly M.J., and Mbogo C., 2014, Pyrethroid susceptibility of malaria vectors in four Districts of western Kenya. Parasites \& Vectors, 7: 310 https://doi.org/10.1186/1756-3305-7-310 PMid:24996418 PMCid:PMC4094666

Odiere M., Bayoh M.N., Gimnig J.E., Vulule J.M., Irungu L., and Walker E.D., 2007, Sampling outdoor, resting Anopheles gambiae and other mosquitoes (Diptera: Culicidae) in western Kenya with clay pots. Journal of Medical Entomology, 44: 14-22 https://doi.org/10.1603/0022-2585(2007)44[14:SORAGA]2.0.CO;2

Ogoma S.B., Kannady K., Sikulu M., Chaki P.P., Govella N.J., Mukabana W.R., and Killeen G.F., 2009, Window screening, ceilings and closed eaves as sustainable ways to control malaria in Dar es Salaam, Tanzania, Malaria Journal, 8: 221 https://doi.org/10.1186/1475-2875-8-221

Osório H.C., Zé-Zé L., Amaro F., and Alves M.J., 2014, Mosquito Surveillance for Prevention and Control of Emerging Mosquito-Borne Diseases in Portugal 2008-2014, International Journal of Environmental Research and Public Health,11: 11583-11596 https://doi.org/10.3390/ijerph111111583 PMid:25396768 PMCid:PMC4245631

Paaijmans K.P., and Thomas M.B., 2011, The influence of mosquito resting behaviour and associated microclimate for malaria risk, Malaria Journal, 10:183 https://doi.org/10.1186/1475-2875-10-183 PMid:21736735 PMCid:PMC3146900 
Pombi M., Guelbeogo W.M., Kreppel K., Calzetta, M., Traoré A., Sanou A., Ranson H., Ferguson H.M., Sagnon, N.F., and Torre, A.D., 2014, "The Sticky Resting Box, a new tool for studying resting behaviour of Afrotropical malaria vectors," Parasite \& Vector. 7(1): 247 https://doi.org/10.1186/1756-3305-7-247 PMid:24885432 PMCid:PMC4049408

Ranson H., and Lissenden N., 2016, Insecticide Resistance in African Anopheles Mosquitoes: A Worsening Situation that Needs Urgent Action to Maintain Malaria Control. Trends in Parasitology, 32(3):187-196

https://doi.org/10.1016/j.pt.2015.11.010

PMid:26826784

Ricci F., 2012, Social implications of malaria and their relationships with poverty, Mediterranean Journal of Hematology and Infectious Diseases, 4: e2012048 https://doi.org/10.4084/mjhid.2012.048 PMid:22973492 PMCid:PMC3435125

Roberts D., and Matthews G., 2016, Risk factors of malaria in children under the age of five years old in Uganda, Malar J. 15: 246 https://doi.org/10.1186/s12936-016-1290-X PMid:27121122 PMCid:PMC4848810

Siegert P.Y., Walker E., and Miller J.R., 2009, Differential behavioral responses of Anopheles gambiae (Diptera: Culicidae) modulate mortality caused by pyrethroid-treated bed nets. Journal of Economic Entomology, 102: 2061-2071

https://doi.org/10.1603/029.102.0607 PMid:20069832

Takken W., and Verhulst N.O., 2013, Host preferences of blood-feeding mosquitoes, Annul Review of Entomology, 58:433-453 https://doi.org/10.1146/annurev-ento-120811-153618 PMid:23020619

Tchouassi D.P., Quakyi I.A., Addison E.A., Bosompem K.M., Wilson M.D., Appawu M.A., BrownC.A., and Boakye D.A., 2012, Characterization of malaria transmission by vector populations for improved interventions during the dry season in the Kpone-on-Sea area of coastal Ghana, Parasite \& Vectors, 5:212 https://doi.org/10.1186/1756-3305-5-212 PMid:23013551 PMCid:PMC3495633

Tusting L.S., Ippolito M.M., Willey B.A., Kleinschmidt I., Dorsey G., and Gosling R.D., 2015, The evidence for improving housing to reduce malaria: a systematic review and meta-analysis, Malaria Journal, 14:209

https://doi.org/10.1186/s12936-015-0724-1 PMid:26055986 PMCid:PMC4460721

von Seidlein L., Ikonomidis K., Mshamu S., Nkya T.E., Mukaka M., Pell C., Lindsay S.W., Deen J.L., Kisinza W.N., and Knudsen J.B., 2017, Affordable house designs to improve health in rural Africa: a field study from northeastern Tanzania, Lancet Planet Health, 1: e188-99 https://doi.org/10.1016/S2542-5196(17)30078-5

Wanjala C.L., Mbugi J.P., Ototo E., Gesuge M., Afrane Y.A., Atieli H.E., Zhou G., Githeko A.K., and Yan G., 2015, Pyrethroid and DDT Resistance and Organophosphate Susceptibility among Anopheles spp. Mosquitoes, Western Kenya. Emerging Infectious Diseases, 21 (12): $2178-2181$ https://doi.org/10.3201/eid2112.150814 PMid:26583525 PMCid:PMC4672417

WHO, 2012, World malaria report 2012, Geneva: World Health Organization; 2012. pp. 1-276 WHO, 2018, Efficacy-Testing of Traps for Control of Aedes Spp. Mosquito Vectors, WHO/CDS/NTD/VEM/2018.06 WHO, 2018, World malaria report, Geneva: World Health Organization; 2018

Yugi J.O., Okeyo-Owuor J.B., Auma C.A., Juma J.I., and Vulule, J.M., 2015,Larviciding potency of water and ethanol extracts of Phytolaccadodecandra (L' Herit) on Anopheles gambiae (Diptera: Culicidae). Journal of Mosquito Research, 5(2): 1-6 https://doi.org/10.5376/jmr.2015.05.0002 